\title{
The production of perennial ryegrass and kikuyu pastures in south-eastern Australia under warmer and drier future climate scenarios
}

\author{
$\underline{\text { M.J. Bell }}^{\text {a }}$, B.R. Cullen ${ }^{\text {a }}$ and R.J. Eckard ${ }^{\text {ab }}$ \\ ${ }^{a}$ Melbourne School of Land and Environment, University of Melbourne, Vic. 3010, Australia \\ ${ }^{b}$ Department of Primary Industries, 1301 Hazeldean Road, Ellinbank, Vic. 3820, Australia \\ Email: Matt.Bell@unimelb.edu.au
}

\begin{abstract}
Grazed pastures in south-eastern Australia are typically based on temperate (C3) species, such as perennial ryegrass (Lolium perenne). With predictions for warmer and drier future climates there has been growing interest in the performance of more heat tolerant and deep rooted subtropical (C4) pasture species such as kikuyu (Pennisetum clandestinum). This study uses an existing pasture model to investigate the production of kikuyu grass compared to the commonly used perennial ryegrass in four regions of southeastern Australia under historical and future climate scenarios.

Four sites were chosen to represent a range of climatic zones and soil types within south-eastern Australia: Dookie in northern Victoria, Hamilton in south-western Victoria, Ellinbank in west Gippsland and Elliott in north-western Tasmania. The biophysical SGS Pasture Model was used to estimate pasture production ( $t$ of dry matter (DM)/ha), metabolisable energy (ME) content and total ME yield (GJ/ha). The ME yield of a kikuyu/subterranean clover (Trifolium subterranean) pasture and a perennial ryegrass/subterranean clover pasture were modelled for a range of temperature and rainfall scenarios projected for southern Australia over the next 60 years. To represent the range of climate scenarios, the baseline climate from the years 1971 to 2000 was adjusted by a:

- $0,1,2,3$ and $4^{\circ} \mathrm{C}$ increase in average daily temperature (with a corresponding 380, 435, 535, 640 and 750 parts per million atmospheric carbon dioxide concentration); and

- $-30,-20,-10,0$ and $+10 \%$ changes in annual rainfall.
\end{abstract}

This created a matrix of 25 climate scenarios. Sheep (wethers maintaining a liveweight of $45 \mathrm{~kg}$ ) were used to maintain the pasture herbage mass at $2.0 \mathrm{t} \mathrm{DM} / \mathrm{ha}$ by adjusting their stocking rate. Nitrogen was supplied to the dryland grazing system so that it was non-limiting to plant growth.

This study showed that across sites less rainfall reduced the ME yield for both species. The kikuyu ME yield responded more strongly to an increase in temperature, up to $4^{\circ} \mathrm{C}$, whereas the annual ME yield of perennial ryegrass began to plateau or decline at 3 to $4^{\circ} \mathrm{C}$ warming. Given future projected climatic changes, this study suggests that it would not be beneficial for kikuyu grass to be the main source of ME per hectare at each site compared to the average ME yield provided by perennial ryegrass, across levels of rainfall studied, until temperatures were to increase by $3,1,2,3^{\circ} \mathrm{C}$ at Dookie, Ellinbank, Elliott and Hamilton, respectively. However, across sites, kikuyu grass could provide a useful source of ME during the months of December to February compared to perennial ryegrass.

Keywords: Kikuyu, perennial ryegrass, modelling, climate change, production 


\section{INTRODUCTION}

In the south-east of Australia the grazing systems are largely dependent on the productivity of perennial grass and clover pastures. The climate across this region can range from medium to high rainfall. On the subtropical east coast, tropical C4 grass species such as kikuyu (Pennisetum clandestinum) are already a major component of pastures (Neal et al., 2007), but are becoming increasingly prevalent across coastal southern Australia. Whereas, C3 grasses such as perennial ryegrass (Lolium perenne) dominate temperate pasture systems further south. Tropical C4 grass species are characterised by being more heat tolerant, cold sensitive and deeper rooting than a temperate $\mathrm{C} 3$ species such as perennial ryegrass. Given these attributes kikuyu has been found to provide a productive and persistent pasture-base, with peak growth during the warmer and drier summer months; when complementing a non-summer active subterranean clover (Trifolium subterranean) and annual grass-based system (McDowall et al., 2003). Kikuyu has the added benefits of being an efficient user of water (Neal et al., 2011) and its rhizomatous and stoloniferous nature can help minimise soil erosion (McDowall et al., 2003).

However, uncertain future climate projections might be, the variability in annual pasture production in southeastern Australia, which has been influenced by climatic conditions, has been within the range experienced historically (Cullen et al., 2011). Predictions are for a warmer and drier environment in southern Australia, with average daily temperatures forecast to rise by up to a $5^{\circ} \mathrm{C}$ by 2070 in some regions and annual rainfall changes of -30 to $+5 \%$ (CSIRO and BOM, 2007; Cullen et al., 2009). The increase in daily temperatures and elevated atmospheric carbon dioxide $\left(\mathrm{CO}_{2}\right)$ concentration and the change in annual rainfall for future climates will influence the quantity and quality of pasture, as conditions may become more favourable for $\mathrm{C} 4$ rather than C3 grass species (Howden et al., 2008). Pasture systems, which form an affordable source of nutrients to livestock systems, need to be robust to both the inter-annual variability in climate and the longerterm projected climatic changes (Cullen et al., 2009). However, the relatively high fibre content of tropical grasses means that they tend to be less digestible than temperature species (Howden et al., 2008). If the composition of naturalised and improved pastures is to become more abundant with tropical grasses, Howden et al. (2008) highlighted the need for research to assess the implications on the nutritional quality of the sward and livestock productivity. Moir et al. (1979) studied dairy cows grazing kikuyu pasture and found that high milk producing animals were firstly limited by the energy concentration of the grass rather than other dietary attributes. Ruminant livestock are generally first limited by energy or protein in their diet, but in most cases the animal can meet its metabolisable protein requirement from grazed forages (Kerley and Lardy, 2007). Exceptions to this may be growing animals or grazing dairy cows that respond to supplementation of protein due to a greater demand for amino acids to support protein synthesis for lean growth or milk production (Kerley and Lardy, 2007).

A whole farm systems biophysical model can help integrate the complexity of climate, soil properties and a grazing animal to simulate the growth response of a pasture sward and help estimate its animal production potential. This study uses an existing pasture model to investigate the nutritional potential for kikuyu grass to be used in grazing systems, now and in future climate scenarios, compared to the commonly used perennial ryegrass in four regions of south-eastern Australia.

\section{MATERIALS AND METHODS}

\subsection{Sites and pasture systems simulated}

The four sites simulated in south-eastern Australia were chosen to represent a range of climatic zones and soil types, as shown in Table 1. A pasture system containing the commonly found perennial ryegrass was compared to a pasture containing kikuyu. Perennial ryegrass and kikuyu pastures were both simulated as a mixed sward with subterranean clover (referred to as subclover). Subclover was considered a compatible legume to use for the comparison of perennial ryegrass and kikuyu.

Table 1. Sites studied and their soil type (Isbell, 1996), mean annual rainfall and mean daily minimum and maximum temperature (from the years 1971 to 2000)

\begin{tabular}{lcccccc}
\hline Site & Location & Lat., Long. & Soil type & Rainfall $(\mathrm{mm})$ & Tmin $\left({ }^{\circ} \mathrm{C}\right)$ & $\operatorname{Tmax}\left({ }^{\circ} \mathrm{C}\right)$ \\
\hline Dookie & N Victoria & $-36.37,145.70$ & Brown chromosol & 592 & 8.0 & 20.2 \\
Ellinbank & W Gippsland & $-38.25,145.93$ & Red Mesotrophic & 1078 & 8.8 & 18.5 \\
& & & Haplic Ferrosol & & 7.7 & 15.7 \\
Elliott & NW Tasmania & $-41.08,145.77$ & Red Mesotrophic & 1220 & 7.7 \\
\hline
\end{tabular}


Dryland (i.e. rainfed) pasture systems were simulated at each site and nitrogen (N) was supplied so that it was non-limiting to plant growth. Fertiliser $\mathrm{N}$ was applied when soil $\mathrm{N}$ became limiting to plant growth, so that $30 \mathrm{~kg} \mathrm{~N} / \mathrm{ha}$ in the form of urea was applied when plant growth was limited by $5 \%$ or more by a lack of $\mathrm{N}$. The pasture was grazed by sheep (wethers maintaining a liveweight of $45 \mathrm{~kg}$ ) and the number of animals was adjusted to maintain the pasture herbage mass at $2.0 \mathrm{t}$ dry matter (DM)/ha. This grazing management rule was implemented so as not to bias the production of grasses in future climate scenarios by applying inappropriate grazing management. No additional feed was supplied to the animals.

\subsection{Pasture model}

The biophysical SGS Pasture Model version 4.8.16 (Johnson et al., 2003) was used to simulate the pasture systems in this study. The SGS model has been shown to provide an acceptable prediction of pasture production at a range of sites in Australia and New Zealand (Cullen et al., 2008; Lodge and Johnson, 2008). Growth of each grass species in the model is described by the plant's photosynthesis and respiration response. Figure 1 shows the assumed rate of photosynthesis of perennial ryegrass and kikuyu at a range of temperatures.

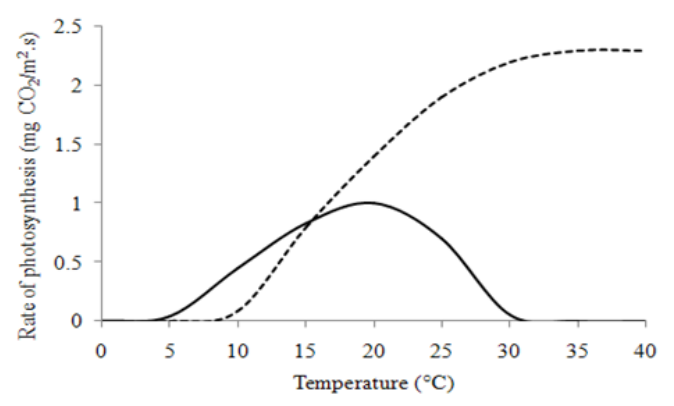

Figure 1. Rate of photosynthesis $\left(\mathrm{mg} \mathrm{CO}_{2} / \mathrm{m}^{2} . \mathrm{s}\right)$ of perennial ryegrass (-) and kikuyu (---) grass species at a range of temperatures.

The maximum rate of photosynthesis (Pmax) was defined as 1 and $2.3 \mathrm{mg} \mathrm{CO} / \mathrm{m}^{2}$.s for perennial ryegrass and kikuyu respectively. The photosynthetic growth response of subclover was similar to perennial ryegrass but Pmax was 0.8 $\mathrm{mg} \mathrm{CO} 2 / \mathrm{m}^{2}$.s. Net growth was linearly reduced between the temperatures of 1 to $8^{\circ} \mathrm{C}$ and 34 to $39^{\circ} \mathrm{C}$ for kikuyu, 0 to $2^{\circ} \mathrm{C}$ and 28 to $35^{\circ} \mathrm{C}$ for perennial ryegrass and -2 to $3^{\circ} \mathrm{C}$ and 28 to $35^{\circ} \mathrm{C}$ for subclover to simulate the effect of extreme temperatures on plant senescence and decay.

The SGS model incorporates daily climate data, soil properties, pasture species, livestock and management to describe the whole farm system. The climate data inputs include minimum and maximum temperature $\left({ }^{\circ} \mathrm{C}\right)$, rainfall $(\mathrm{mm})$, solar radiation $\left(\mathrm{MJ} / \mathrm{m}^{2}\right)$, vapour pressure $(\mathrm{kPa})$ and minimum and maximum relative humidity (\%).
The baseline climate data for each site were obtained from the SILO database (Jeffery et al., 2001) for the years 1961 to 2000 . The first 10 years of each simulation were discarded to allow the nutrient dynamics within the model to reach a steady state, which left a baseline dataset from 1971 to 2000 for further analysis.

\subsection{Climate scenarios and data analysis}

The daily pasture production ( $\mathrm{kg} \mathrm{DM} / \mathrm{ha}$ ), digestibility $(\%)$ and crude protein content $(\mathrm{g} / \mathrm{kg}$ DM) were obtained from simulations at each site. The percentage of digestible $(\delta)$ plant material was calculated by equation 1 (Johnson et al., 2003):

$$
\delta=f_{p}+f_{s}+\delta_{w} f_{w}
$$

Where $f, p, s$, and $w$ represent the fraction of plant protein, sugars and cell wall material, respectively. The model assumed that the fraction of plant protein and sugars were completely digestible. Whereas, it was assumed that the cell wall material of perennial ryegrass had a digestibility of $70 \%$, whereas the digestibility of kikuyu and subclover were $65 \%$. The metabolisable energy (ME) content of the pasture was estimated using equation (2) by Minson and McDonald (1987):

$$
\mathrm{ME}(\mathrm{MJ} / \mathrm{kg} \mathrm{DM})=0.1604 \times \delta-1.037
$$

The ME content was converted to ME yield (GJ/ha) by multiplying by the pasture production per hectare. The ME yield was used as a measure of the nutritional quality associated with the perennial ryegrass/subclover and kikuyu/subclover pastures for:

- The years 1971 to 2000 (baseline)

- The baseline adjusted for a range of temperature and rainfall scenarios, which were:

○ $0,1,2,3$ and $4^{\circ} \mathrm{C}$ increase in average daily temperature with a corresponding concentration of $380,435,535,640$ and 750 parts per million in atmospheric $\mathrm{CO}_{2}$ respectively (IPCC, 2000); and 
Bell et al., Production of perennial ryegrass and kikuyu pastures under future climate scenarios

○ $-30,-20,-10,0$ and $+10 \%$ changes in annual rainfall.

Due to the uncertainties associated with projected future climatic changes, a range of temperature and rainfall changes were adopted based on those projected for southern Australia over the next 60 years (CSIRO and BOM, 2007; Cullen et al., 2009). Trends in monthly and annual ME yields were evaluated for each pasture system at each site.

\section{RESULTS}

\subsection{Pasture production and its quality during baseline years}

On average a kikuyu/subclover pasture at each site was less digestible (ranging from 65 to $70 \%$ for kikuyu compared to 69 to $75 \%$ for ryegrass) and had a poorer crude protein content than the perennial ryegrass/subclover pasture $(0.21 \mathrm{~g} / \mathrm{kg}$ DM for kikuyu compared to 0.25 to $0.26 \mathrm{~g} / \mathrm{kg} \mathrm{DM}$ for ryegrass; Table 2). The digestibility of both pasture systems was greater at sites with higher rainfall such as Ellinbank and Elliott. Table 2 also shows that on average the monthly production of kikuyu pasture was higher at Dookie and Ellinbank in comparison to the perennial ryegrass pasture, however, the production of the kikuyu pasture was more variable. At Dookie the average monthly ME yield of kikuyu was higher than that of perennial ryegrass and at Ellinbank it was similar.

\subsection{Pasture production and quality in future climate scenarios}

Using Ellinbank as an example, Figure 3 shows that an increase in warming of $+2^{\circ} \mathrm{C}$ would benefit pasture growth in both pasture systems. Warming by $+2^{\circ} \mathrm{C}$ increased the production on average of the perennial ryegrass/subclover pasture between June and October compared to March to December for the kikuyu/subclover pasture (Figure 3).
Table 2. Average monthly pasture production and standard deviation (s.d.), digestibility, metabolisable energy yield and crude protein content predicted during the baseline years (1971 to 2000) for the perennial ryegrass/subclover and kikuyu/subclover pastures at Dookie, Hamilton, Ellinbank and Elliott

\begin{tabular}{|c|c|c|c|c|}
\hline \multirow[b]{3}{*}{ Site } & \multicolumn{4}{|c|}{ Pasture system } \\
\hline & \multicolumn{3}{|c|}{ Perennial ryegrass } & Kikuyu \\
\hline & Mean & s.d. & Mean & s.d. \\
\hline \multicolumn{5}{|l|}{ Dookie } \\
\hline Production (t DM/ha) & 0.53 & 0.43 & 0.65 & 0.67 \\
\hline Digestibility (\%) & 69 & 6.4 & 65 & 6.7 \\
\hline ME yield (GJ/ha) & 6.0 & 4.9 & 6.7 & 7.4 \\
\hline $\begin{array}{l}\text { Crude protein }(\mathrm{g} / \mathrm{kg} \\
\mathrm{DM})\end{array}$ & 0.25 & 0.004 & 0.21 & 0.005 \\
\hline \multicolumn{5}{|l|}{ Hamilton } \\
\hline Production (t DM/ha) & 0.79 & 0.40 & 0.51 & 0.35 \\
\hline Digestibility (\%) & 71 & 4.7 & 66 & 4.4 \\
\hline ME yield (GJ/ha) & 9.1 & 4.7 & 5.2 & 3.9 \\
\hline $\begin{array}{l}\text { Crude protein }(\mathrm{g} / \mathrm{kg} \\
\mathrm{DM})\end{array}$ & 0.25 & 0.004 & 0.21 & 0.003 \\
\hline \multicolumn{5}{|l|}{ Ellinbank } \\
\hline Production (t DM/ha) & 1.05 & 0.40 & 1.17 & 0.61 \\
\hline Digestibility (\%) & 74 & 3.7 & 70 & 3.6 \\
\hline ME yield (GJ/ha) & 12 & 4.7 & 12 & 6.8 \\
\hline $\begin{array}{l}\text { Crude protein }(\mathrm{g} / \mathrm{kg} \\
\mathrm{DM})\end{array}$ & 0.26 & 0.004 & 0.21 & 0.003 \\
\hline \multicolumn{5}{|l|}{ Elliott } \\
\hline Production (t DM/ha) & 1.01 & 0.45 & 0.84 & 0.48 \\
\hline Digestibility (\%) & 75 & 4.1 & 70 & 3.4 \\
\hline ME yield (GJ/ha) & 12 & 5.3 & 8.9 & 5.3 \\
\hline $\begin{array}{l}\text { Crude protein }(\mathrm{g} / \mathrm{kg} \\
\mathrm{DM})\end{array}$ & 0.26 & 0.004 & 0.21 & 0.003 \\
\hline
\end{tabular}



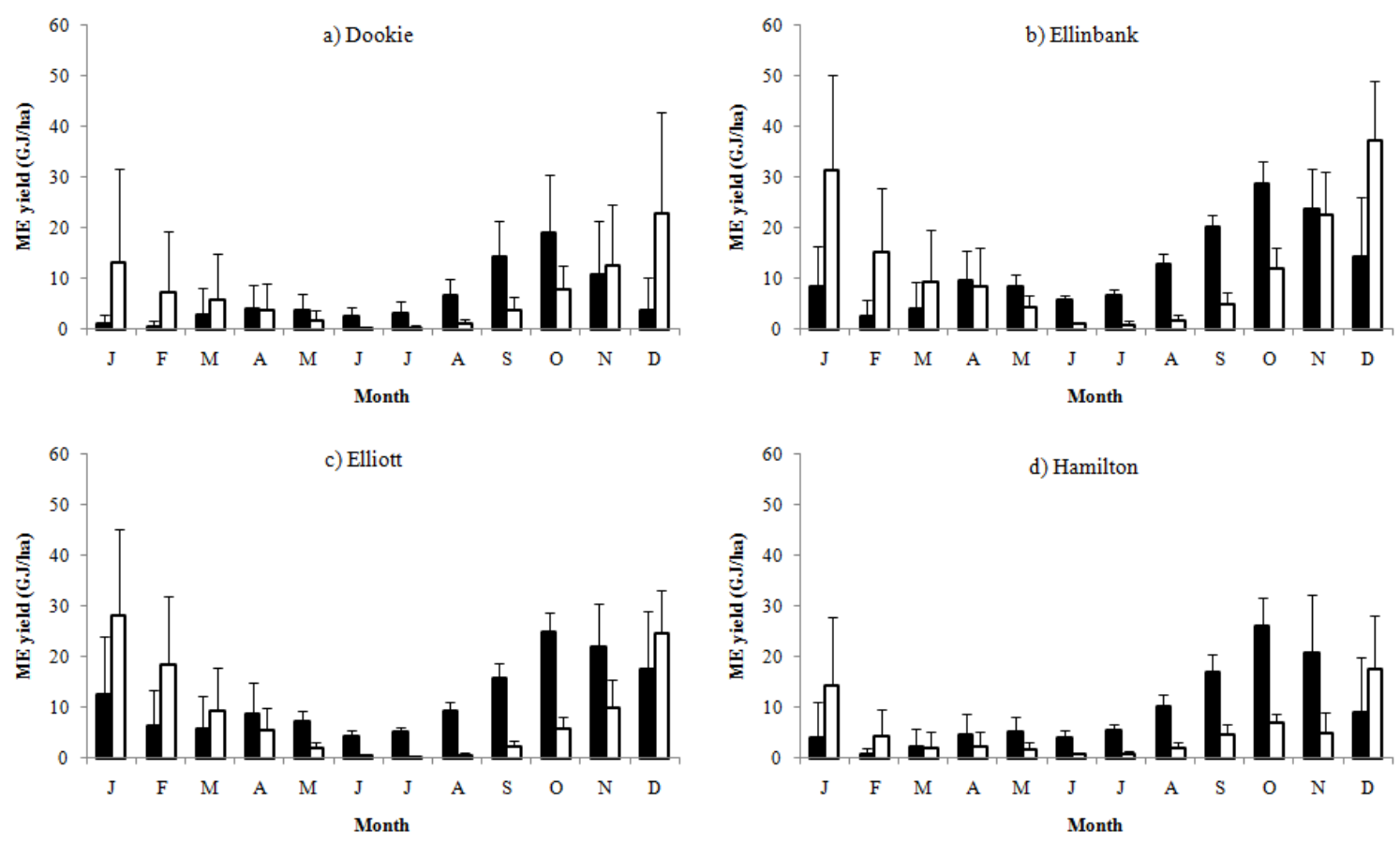

Figure 2. Average monthly metabolisable energy (ME) yield (GJ/ha) predicted for perennial ryegrass/subclover ( $\mathbf{(}$ ) and kikuyu/subclover ( $\square$ ) at a) Dookie b) Hamilton c) Ellinbank and d) Elliott during the baseline years of 1971 to 2000 .
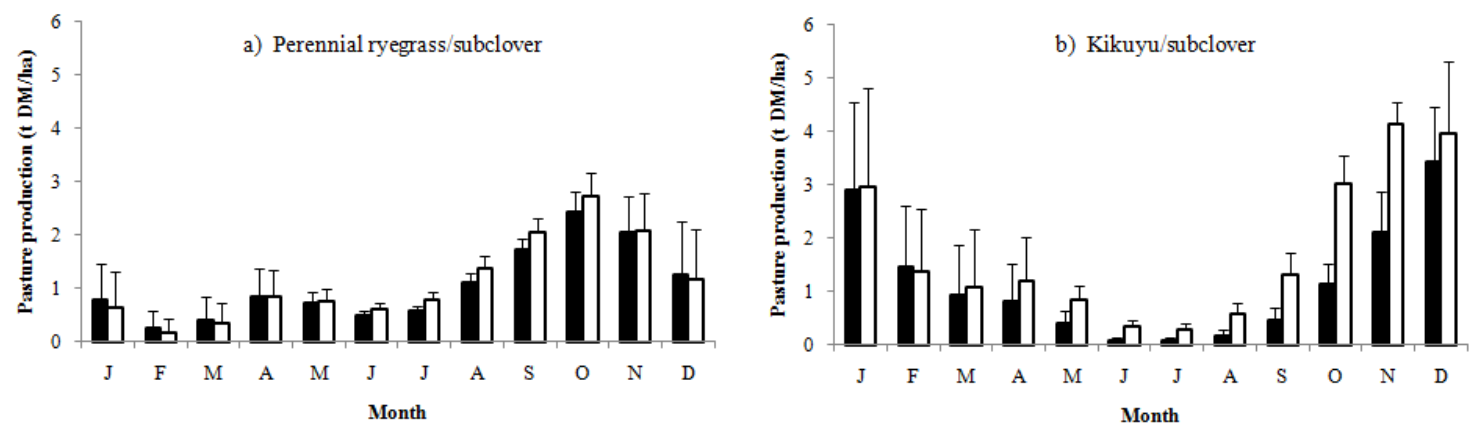

Figure 3. Average monthly pasture production (t DM/ha) predicted for a) perennial ryegrass/subclover and b) kikuyu/subclover at Ellinbank during the baseline years of 1971 to $2000(\mathbf{m})$ and with warming of $+2^{\circ} \mathrm{C}$ and an increase in atmospheric $\mathrm{CO}_{2}$ concentration from 380 to $535 \mathrm{ppm}$ (口).

On average, the pasture production of the perennial ryegrass/subclover pasture begins to decline during the months of December to March (Figure 3). This has an impact on annual ME yield (Figure 4), as the annual yields of ME of perennial ryegrass/subclover pasture appear to plateau or decline with a temperature increase of more than $2^{\circ} \mathrm{C}$ across sites when compared to the historical annual average (baseline value represented by 0T 100R for ryegrass). Whereas, higher average temperatures generally increased kikuyu productivity across all sites (Figure 4). Figure 4 shows that on an annual basis, less rainfall reduced the ME yield of both pasture systems, due to its impact on pasture production. 

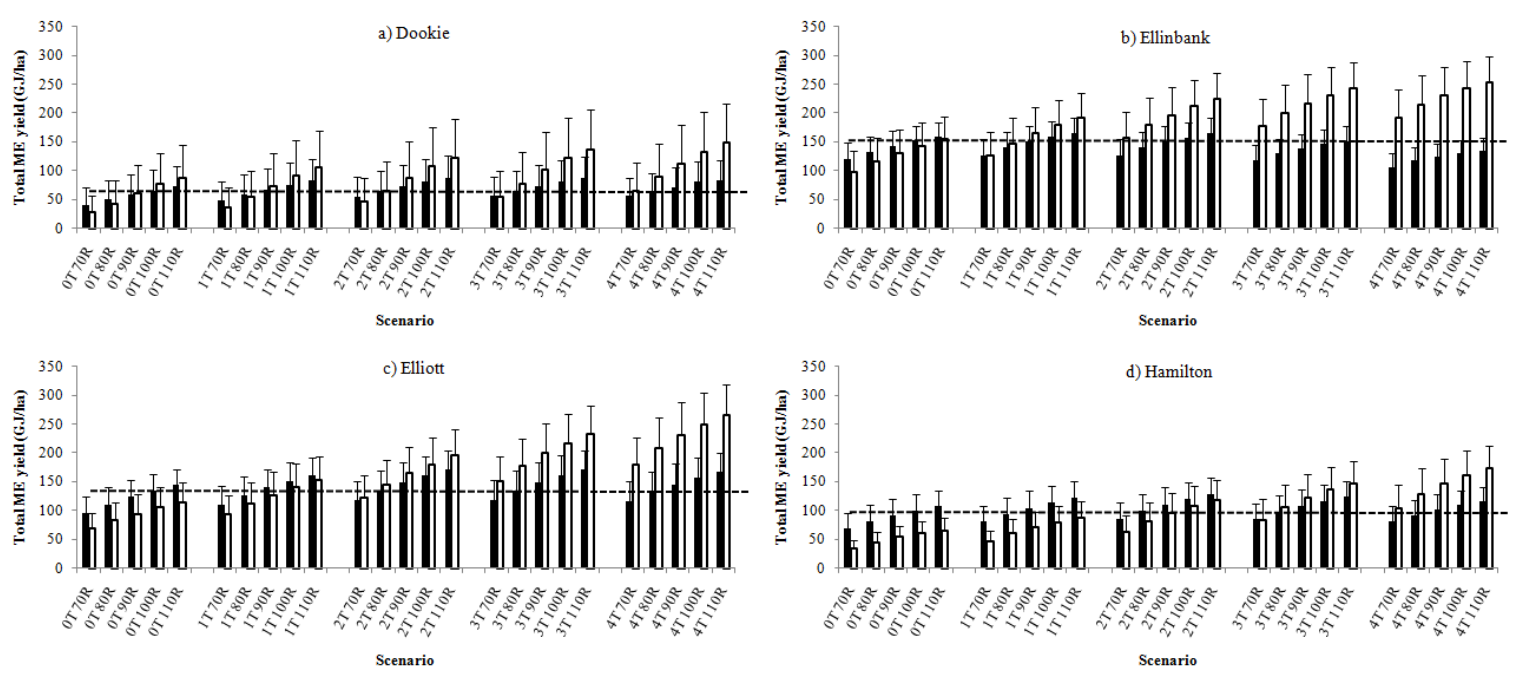

Figure 4. Average total metabolisable energy (ME) yield (GJ/ha) predicted for perennial ryegrass/subclover (匹) and kikuyu/subclover ( $\square$ ) at a) Dookie b) Ellinbank c) Elliott and d) Hamilton for each combination of temperature increase from $0^{\circ} \mathrm{C}(0 \mathrm{~T})$ to $4^{\circ} \mathrm{C}(4 \mathrm{~T})$ and $-30(70 \mathrm{R})$ to $+10 \%(110 \mathrm{R})$ change in annual rainfall. The average $\mathrm{ME}$ yield for perennial ryegrass/subclover during the baseline years of 1971 to 2000 (scenario 0T 100R) is highlighted (- -).

It would not be beneficial for kikuyu grass to be the main source of ME per hectare at each site compared to the average ME yield provided by perennial ryegrass (Figure 4), across all levels of rainfall studied, until temperatures were to increase by $3,1,2,3^{\circ} \mathrm{C}$ at Dookie, Ellinbank, Elliott and Hamilton, respectively.

\section{DISCUSSION AND CONCLUSIONS}

The SGS Pasture Model in this study gave a realistic representation of the growth response of kikuyu under a mixed sward grazing system (Sandford et al., 2003) and its nutritional quality (Marais, 2001). The digestibility and crude protein content of the pasture containing kikuyu, which is a summer and autumn dominant grass, was predictably lower than the pasture containing the non-summer active perennial ryegrass (Kerley and Lardy, 2007; Howden et al., 2008). Generally, kikuyu responded to higher average temperatures with elevated atmospheric $\mathrm{CO}_{2}$ concentrations, whereas the annual ME yield of perennial ryegrass plateaued or declined when baseline temperatures increased by more than $2^{\circ} \mathrm{C}$. At the sites studied, the potential for the kikuyu species within a pasture system appears to lie with its productivity during the summer months of December to February. The productivity of kikuyu may be extended beyond these months, with a larger proportion of a farm's pasture-base being sown to this species to maintain a productive grazing system throughout the year if conditions get warmer. This study showed that at the Ellinbank site, the growth of the kikuyu/subclover pasture was more responsive to an increase in warming of $2{ }^{\circ} \mathrm{C}$ during the cooler nonsummer months and conditions became more favourable for the more water use efficient kikuyu. However, it appears that if rainfall is to decline in southern Australia, this will reduce the productivity and ME yield of both the kikuyu and perennial ryegrass pastures. A decline in autumn and spring rainfall as reported by Gallant et al. (2007) will impact more on the non-summer active perennial ryegrass pasture system.

In conclusion, given projected climatic changes, this study suggests that on average kikuyu grass could not annually provide a greater source of $\mathrm{ME}$ per hectare at each site compared to perennial ryegrass, across all levels of rainfall studied, until temperatures were to increase by $3,1,2,3^{\circ} \mathrm{C}$ at Dookie, Ellinbank, Elliott and Hamilton, respectively. However, during the months of December to February kikuyu could currently provide a useful source of green feed at the sites studied, which is not provided by perennial ryegrass.

\section{ACKNOWLEDGMENTS}

This work was supported by funding from Dairy Australia, Meat and Livestock Australia and the Australian Government Department of Agriculture, Fisheries and Forestry under its Australia's Farming Future Climate Change Research Program. 
Bell et al., Production of perennial ryegrass and kikuyu pastures under future climate scenarios

\section{REFERENCES}

CSIRO and BOM (2007). Climate change in Australia. Technical report 2007. (Eds K. B. Pearce, P. N. Holper, M. Hopkins, W. J. Bouma, P. H. Whetton, K. J. Hensessy and S. B. Power), p. 148. Aspendale, Victoria, Australia: CSIRO Marine and Atmospheric Research. http://www.climatechangeinaustralia.gov.au/

Cullen, B.R., Eckard, R.J., Callow, M.N., Johnson, I.R., Chapman, D.F., Rawnsley, R.P., Garcia, S.C., White, T. and Snow, V.O. (2008). Simulating pasture growth rates in Australian and New Zealand grazing systems. Australian Journal of Agricultural Research, 59, 761-768.

Cullen, B.R., Johnson, I.R., Eckard, R.J., Lodge, G.M., Walker, R. G., Rawnsley, R. P. \& McCaskill, M. R. (2009). Climate change effects on pasture systems in south-eastern Australia. Crop \& Pasture Science, 60, 933-942.

Cullen, B.R., Bell, M.J., Christie, K.M., Rawnsley, R.P. and Eckard, R.J. (2011). Trends in annual pasture production and its variability. Proceedings of the $52^{\text {nd }}$ Annual Conference of the Grassland Society of Southern Australia. 2-3 June, Hamilton, Victoria, pp.117-120.

Gallant, A.J.E., Hennessey, K.J. and Risbey, J. (2007). Trends in rainfall indices for six Australian regions: 1910-2005. Australian Meteorology Magazine, 56, 223-239.

Howden, S.M., Crimp, S.J. and Stokes, C.J. (2008). Climate change and Australian livestock systems: impacts, research and policy issues. Australian Journal of Experimental Agriculture, 48, 780-788.

IPCC (2000). Emissions scenarios. Special Report of the Intergovernmental Panel on Climate Change. Nakicenovic, N and Swart, R. (Eds.), Cambridge University Press, Cambridge, UK.

Isbell, R.F. (1996). Australian soil and land survey handbook: the Australian soil classification. CSIRO Publishing: Collingwood, Vic.

Jeffrey, S.J., Carter, J.O., Moodie, K.M. and Beswick, A.R. (2001). Using spatial interpolation to construct a comprehensive archive of Australian climate data. Environmental Modelling \& Software, 16, 309-330.

Johnson, I.R., Lodge, G.M. and White, R.E. (2003). The Sustainable Grazing Systems Pasture Model: description, philosophy and application to the SGS National Experiment. Australian Journal of Experimental Agriculture, 43, 711-728.

Kerley, M.S. and Lardy, G.P. (2007). Grazing animal nutrition In: Barnes, R.F, Nelson, C.J., Moore, K.J. and Collins, M. (Eds.), Forages, Volume II: The Science of Grassland Agriculture, 6th ed. Iowa State Press, Ames, US. pp. 660-673.

Lodge, G.M. and Johnson, I.R. (2008). Agricultural drought analyses for temperate Australia using a biophysical pasture model. 1. Identifying and characterising drought periods. Australian Journal of Agricultural Research, 59, 1049-1060.

Marais, J.P. (2001). Factors affecting the nutritive value of kikuyu grass (Pennisetum clanestinum) - a review. Tropical Grasslands, 35, 65-84.

McDowall, M.M., Hall, D.J.M., Johnson, D.A., Bowyer, J. and Spicer, P. (2003). Kikuyu and annual pasture: a characterization of a productive and sustainable beef production system on the South Coast of Western Australia. Australian Journal of Experimental Agriculture, 43, 769-783.

Minson, D.J. and McDonald, C.K. (1987). Estimating forage intake from the growth of beef cattle. Tropical Grasslands, 21, 116-122.

Moir, K.W., Dougherty, H.G., Goodwin, P.J., Humphreys, F.J. and Martin, P.R. (1979). An assessment of whether energy was the first factor limiting production of dairy cows grazing kikuyu grass pasture. Australian Journal of Experimental Agriculture, 19, 530-534.

Neal, J.S., Fulkerson, W.J. and Sutton, B.G. (2011). Differences in water-use efficiency among perennial forages used by the dairy industry under optimum and deficit irrigation. Irrigation Science, 29, 213-232.

Neal, M., Neal, J. and Fulkerson, W.J. (2007). Optimal choice of dairy forages in eastern Australia. Journal of Dairy Science, 90, 3044-3059.

Sandford, P., Wang, X., Greathead, K.D., Gladman, J.H. and Speijers, J. (2003). Impact of Tasmanian blue gum belts and kikuyu-based pasture on sheep production and groundwater recharge in south-western Western Australia. Australian Journal of Experimental Agriculture, 43, 755-767. 